\title{
Generational Sensitivity Alteration in Chironomus Yoshimatsui to Carbamate and Pharmaceutical Chemicals and The Effect on Catalase, CYP450, and Hemoglobin Gene Transcription
}

\author{
Makoto Ishimota ( $\nabla$ mota-4024will@hotmail.co.jp ) \\ The Institute of Environmental Toxicology https://orcid.org/0000-0003-4686-0244 \\ Naruto Tomiyama
}

The Institute of Environmental Toxicology

\section{Research Article}

Keywords: Tolerance, Chironomidae, Hemoglobin, Catalase, Carbamates, Pharmaceutical chemical

Posted Date: February 23rd, 2021

DOI: https://doi.org/10.21203/rs.3.rs-209998/v1

License: (c) (1) This work is licensed under a Creative Commons Attribution 4.0 International License. Read Full License

Version of Record: A version of this preprint was published at Ecotoxicology on October 8th, 2021. See the published version at https://doi.org/10.1007/s10646-021-02484-5. 


\section{Abstract}

To ascertain the tolerance mechanisms of aquatic organisms to artificial chemicals, intergenerational sensitivity changes of Chironomus yoshimatsui to a carbamate pesticide (pirimicarb) and pharmaceutical chemical (diazepam) were investigated. The larvae ( $<48$-h-old) in each generation were exposed to both chemicals for $48 \mathrm{~h}$ and then the surviving chironomids were cultured until the fifth generation (FO-F4) without chemical addition. The 48 -h $50 \%$ effective concentration $\left(\mathrm{EC}_{50}\right)$ value of chironomids was determined for each generation. In the pirimicarb treatment group, the $\mathrm{EC}_{50}$ values significantly increased in $\mathrm{F} 3$ and $\mathrm{F} 4$, and those in the diazepam treatment group slightly increased. Catalase, Cytochrome P450 and hemoglobin $(\mathrm{Hb})$ mRNA levels were monitored to see whether these were related to the trans-generational sensitivity. Although the generalized linear model results showed that the sensitivity to diazepam was slightly increased in the diazepam treatment, we could not find any mRNA levels related to sensitivity alteration. In contrast, the model approach showed that the chironomids exposed to pirimicarb trans-generationally became tolerant with increasing $\mathrm{Hb}$ mRNA levels. Therefore, they might decrease their oxidative chemical stress by modifying $\mathrm{Hb}$ gene transcription.

\section{Introduction}

Surface water runoff causes pulsed rather than continuous exposure to chemicals such as pesticides and metals for aquatic organisms (Ashauer et al., 2007; Chen et al., 2012; Trac et al., 2016). Pulsed exposure to such chemicals is expected for pharmaceutical chemicals because these chemicals enter the water via sewage effluent from urban areas, including domestic dwellings or hospitals, as well as sewage released to the aquatic environment when it rains (McLellan et al., 2018; Pascoe et al., 2003). To elucidate the realistic exposure of chemicals to aquatic organisms, we previously investigated whether short-term exposure (48 h) of successive (first and second) generations of Chironomus yoshimatsui ( $<24$-h-old) to acetylcholinesterase (AChE) inhibitor insecticides (pirimicarb and pyraclofos) would change the sensitivity over four generations (Ishimota et al., 2020a). The findings from this previous study showed that the chironomids exposed to pirimicarb produced larvae that were less sensitive than those in the control group and the increased AChE activity might be related to this low sensitivity. However, other enzymes, such as detoxifying enzyme and cytochrome P450 (CYP450) might also alter the sensitivity of chironomids. Chemicals are metabolized by detoxifying enzymes, such as Catalase (CAT), CYP450 and glutathione S-transferases (Wang et al., 1999; Wu and Hoy, 2016). CAT prevents cell oxidative damage by degrading hydrogen peroxide to water and oxygen with high efficiency (Alfonso-Prieto et al., 2009). The CAT mRNA levels in chironomids were significantly altered when they were exposed to chemicals (cadmium and nonylphenol) (Nair et al., 2011). CYP450 is one of the major phase l-type classes of biotransformation enzymes and converts xenobiotic compounds into water-soluble substances (Bonnafé et al., 2015). The relationship between the CYP450 enzyme and toxicity of xenobiotic chemicals to several insects has been studied previously and it has been found that the CYP450 genes were related to insecticide resistance (Dulbecco et al., 2018; Kaplanoglu et al., 2017; Nair et al., 2013; Tang et al., 2017; Yu et al., 2015). The members of the CYP4 family are frequently related to specialized biochemical 
pathways such as the biosynthesis of endogenous compounds and metabolism of pheromones (Xiong et al., 2019). Chironomids are widely distributed worldwide and possess hemoglobin ( $\mathrm{Hb})$ for carrying oxygen from the environment to their respiring tissues (Ha and Choi, 2008). This species can inhabit environments with low oxygen concentrations because of this $\mathrm{Hb}$ (Kawai et al., 2004). A previous study found that the $\mathrm{Hb}$ content increased with decreasing oxygen concentration in C. riparius found in a lowland stream (Manfrin et al., 2018). Because Hb levels in chironomids have been used as a biomarker for chemicals (Choi and Roche, 2004; Ha and Choi, 2008; Lee et al., 2006), the levels might be altered in chemical-tolerant individuals. To ascertain whether the oxidative stress for the target chemicals could be detected by measuring the three kinds of mRNA levels, and to identify the mechanisms underlying intergenerational changes in sensitivity in chironomids, we focused on the changes in CAT, CY450 (CYP4 family), and $\mathrm{Hb}$ mRNA levels in the present multi-generational study.

Pirimicarb and diazepam (which affect the neurons in organisms) were used in the present study. Pirimicarb is a carbamate insecticide that inhibits AChE. This chemical is one of the most detected insecticides in surface water (Struger et al., 2016). We have previously used this chemical for a multigenerational study to ascertain the mechanism for the development of tolerance to carbamate pesticides in chironomids and cladocerans (Ishimota et al., 2020a, b). Diazepam is a pharmaceutical chemical that is classified as a benzodiazepine anxiolytic that binds to the $G_{A B A}$ receptor and increases the channel current by increasing the frequency of the channel openings (Glykys and Staley, 2015; Harris et al., 2009). The channel openings allow the chlorine ions that have flowed into the neurons to move out of the cell and then the neuronal activity decreases. Diazepam has been detected in quantities of several micrograms per liter in rivers in Brazil, Italy, and Germany (Böger et al., 2018; Calamari et al., 2003; Ternes et al., 2001). Exposure of a fish (zebrafish) to diazepam induced behavioral abnormalities (Wu et al., 2020). Considering their potential risks to aquatic organisms, we focused on these two chemicals that have different action mechanisms.

The aims of the present study were to test 1 ) how the pulsed exposure of pirimicarb and diazepam would alter the sensitivity of $C$. yoshimatsui (48-h-old larvae) to these chemicals in a multi-generational study and 2) whether CAT, CYP450 and Hb mRNA levels were related to sensitivity changes. We expected that these mRNA levels would contribute to the mechanisms of the trans-generational effects of these chemicals.

\section{Methods}

\section{Chemical analysis}

Pirimicarb (99.9\% purity) and diazepam (98.0\% purity) were purchased from Fujifilm Wako Pure Chemical Corporation (Osaka, Japan). To determine the concentrations of the chemicals in the water samples, each sample was diluted with acetonitrile: pure water $(60: 40, \mathrm{v} / \mathrm{v})$. The chemicals were quantified by liquid chromatography-mass spectrometry (LC-MS/MS) at a flow rate of $0.3 \mathrm{~mL} / \mathrm{min}$ using a column at $40{ }^{\circ} \mathrm{C}$ (LC: 1290 HPLC; MS/MS: 6460 Triple Quad LC-MS/MS, Agilent Technologies, CA, USA; column: Acquity 
UPLC HSS T3, $1.8 \mu \mathrm{m} \times 2.1 \mathrm{~mm} \times 100 \mathrm{~mm}$, Waters, MA, USA). The operating conditions and mobile phase were in accordance with the procedure outlined by Ishimota et al. (2020a). The monitored precursor/product ions for pirimicarb and diazepam were at 239.1/72.1 and 285.0/193.1 $\mathrm{m} / \mathrm{z}$, respectively. The peak area response for each chemical was determined using a data processor and the calibration curve was constructed by plotting the amount against the peak area of the calibration standard using the least-squares method.

In our previous study, the recovery rates for pirimicarb at $0.5 \mu \mathrm{g} / \mathrm{L}$ and $160 \mathrm{mg} / \mathrm{L}$ were $95 \%$ to $104 \%$ and the relative standard deviations (RSDs) were $1 \%$ to $2 \%$ in the same test medium and the chemical was very stable under these test conditions for $48 \mathrm{~h}$ (Ishimota et al., 2020a). Thus, the analytical accuracy, variation, and stability under the test conditions were checked only for diazepam in the present study. The limit of quantification was $0.5 \mu \mathrm{g} / \mathrm{L}$ for each chemical. The recovery rates and RSDs at $0.5 \mu \mathrm{g} / \mathrm{L}$ and 20 $\mathrm{mg} / \mathrm{L}$ for diazepam were calculated from three spiked water samples. The media containing diazepam $(20 \mathrm{mg} / \mathrm{L})$ were prepared in triplicate. After a 48-h period under test conditions, the diazepam concentration was determined. The diazepam was found to be extremely stable in the water samples during the 48-h exposure period. Thus, the concentrations for each test group were only measured at the beginning of exposure in the present study. The RSDs of the diazepam concentrations in all samples were calculated as per Eqn. (1):

$R S D(\%)=\frac{S D}{\text { Mean }} \times 100$,

where, $S D$ and mean denote the standard deviation and mean of the diazepam concentrations $(n=3)$, respectively.

\section{Test organisms and culture methods}

C. yoshimatsui (NIES clone) was obtained from the National Institute for Environmental Studies (Ibaraki, Japan). The test species had been continuously maintained in ISO medium with a slight modification $\left(\mathrm{CaCl}_{2} \varangle 2 \mathrm{H}_{2} \mathrm{O}: 36.9 \mathrm{mg} / \mathrm{L}, \mathrm{MgSO}_{4} \otimes 7 \mathrm{H}_{2} \mathrm{O}: 6.1 \mathrm{mg} / \mathrm{L}, \mathrm{NaHCO}_{3}: 64.8 \mathrm{mg} / \mathrm{L}, \mathrm{KCl}: 8.60 \mathrm{mg} / \mathrm{L}\right.$, thiamine hydrochloride: $75.0 \mu \mathrm{g} / \mathrm{L}$, cyano-cobalamin: $1.00 \mu \mathrm{g} / \mathrm{L}$, and biotin: $0.75 \mu \mathrm{g} / \mathrm{L}$ ) (Ishimota et al., 2020a) and were fed TetraFin (Tetra, Melle, Germany) at least five times per week at a rate of $0.1 \mathrm{~g}$ per container. The test species were cultured in $5 \mathrm{~L}$ stainless-steel containers (length: $40 \mathrm{~cm}$, width: $27 \mathrm{~cm}$, and height: $7 \mathrm{~cm}$ ) with a net containing $1.5 \mathrm{~L}$ of the medium and $1 \mathrm{~kg}$ of glass beads. The culture medium was changed at least once per week. The test species were maintained under standardized conditions, i.e., a photoperiod of $16: 8 \mathrm{~h}$ light: dark and a light intensity of approximately 800 lux at $23 \pm 1^{\circ} \mathrm{C}$. The egg masses that were produced were collected daily and were used to conduct all the experiments and establish the next generation in the multi-generational study.

Multi-generational experiment 
In our previous multi-generational study of tolerance to chemicals in chironomids, we used $<24$-h-old larvae; however, we used the $>$ 24-h and < 48-h-old (hereafter, $<48$-h-old) larvae for all experiments in the present study because the size of this aged larvae was large enough to detect each of the mRNA levels, whereas that of the $<24$-h-old larvae was not adequate (Ishimota et al., 2020a). Chironomid larvae $(<48-$ h-old) were exposed to low effective concentrations of chemicals and were cultured until an appropriate number of egg masses was obtained for each generation (five successive generations: F0-F4) (Fig. 1). Changes in the larval sensitivity were investigated based on the $48-\mathrm{h} 50 \%$ effective concentration $\left(\mathrm{EC}_{50}\right)$ value across the five generations. Additionally, we measured CAT, CYP450 and Hb mRNA levels in the larvae exposed to the target chemicals in each generation.

Nominal concentrations $(0,5,10,20,40$, and $80 \mathrm{mg} / \mathrm{L}$ for pirimicarb and $0,1.3,2.5,5,10$, and $20 \mathrm{mg} / \mathrm{L}$ for diazepam) were prepared based on the $48-\mathrm{h} \mathrm{EC}_{50}$ value for each chemical in the preliminary tests. To prevent the chironomids from becoming trapped on the surface of the solution, each test solution contained $2 \mu \mathrm{L} / \mathrm{L}$ Tween 80 . After the larvae were fed, five larvae (< 48-h-old) were exposed to $50 \mathrm{~mL}$ test solutions in $100 \mathrm{~mL}$ glass beakers for $48 \mathrm{~h}$ without any food under standardized conditions. We prepared four sets of glass beakers and 20 individuals from each treatment were exposed. After 48-h exposure, the number of larvae that could not change their position during $15 \mathrm{~s}$ of gentle agitation of the beaker (immobility) was counted for each concentration and the $\mathrm{EC}_{50}$ values were calculated from the immobility results for the $\mathrm{F} 0$ samples. The $48-\mathrm{h} \mathrm{EC}_{50}$ values for pirimicarb and diazepam were determined according to the acute toxicity test of the Organization for Economic Co-operation and Development (OECD) guideline "No. 235 Chironomus sp., acute immobilization test" (OECD, 2011). To check the 48-h $\mathrm{EC}_{50}$ value in each generation ( $\mathrm{F} 1, \mathrm{~F} 2, \mathrm{~F} 3$, and $\mathrm{F} 4$ samples), the larvae were exposed to the same method as described for the F0 generation. This experiment for each generation was performed in triplicate using the larvae collected from three egg masses.

To establish the next generation group (control and treatment groups), chironomids were pre-exposed to each chemical as follows. A total of 400 larvae (< 48-h-old) were exposed to the $500 \mathrm{~mL}$ solutions (control group without any exposure and treatment groups containing each chemical, i.e., 0 and $15 \mathrm{mg} / \mathrm{L}$ of pirimicarb and 0 and $5 \mathrm{mg} / \mathrm{L}$ of diazepam in $500 \mathrm{~mL}$ glass beakers without food under standardized conditions). After 48-h exposure, 300 chironomids that had survived were randomly selected from each group and cultured separately without chemicals until enough egg masses for each experiment were obtained. In a previous study, the chironomids developed tolerance to pirimicarb, which caused a decrease in mobility but no mortality (Ishimota et al., 2020a). Thus, the nominal concentrations for each chemical were set at similar levels as those in the previous study for pirimicarb. Controls $(0 \mu \mathrm{g} / \mathrm{L})$ for each generation in culture medium containing $2 \mu \mathrm{L} / \mathrm{L}$ Tween 80 for $48 \mathrm{~h}$ were extracted using the same method described previously. The procedure for culturing the chironomids for each generation was the same as that described in section 2.2.

CAT, CYP450, Hemoglobin and mRNA levels 
We tested how CAT, CYP450 and Hb mRNA levels changed in chironomids exposed to three different concentrations of pirimicarb and diazepam. After the seventy larvae (<48-h-old) were fed, they were exposed to $500 \mathrm{~mL}$ of the test solutions in $500 \mathrm{~mL}$ glass beakers for $48 \mathrm{~h}$ without any food under standardized conditions. We prepared three sets of glass beakers, and 70 individuals from each treatment (i.e., pirimicarb: 0, 15, and $40 \mathrm{mg} / \mathrm{L}$; diazepam: 0, 2.5, and $5.0 \mathrm{mg} / \mathrm{L}$, with each solution containing $2 \mu \mathrm{L} / \mathrm{L}$ Tween 80 ) were exposed to each test solution without food, under standardized conditions for $48 \mathrm{~h}$. We measured the CAT, CYP450 and Hb mRNA levels in the exposed chironomids in each concentration group. Additionally, the CAT, CYP450 and Hb mRNA levels in the chironomids from the control and treatment groups were measured in the multi-generational study. After the chironomid larvae obtained from the control and treatment groups in each generation were fed, they were exposed to 500 $\mathrm{mL}$ of each chemical solution $(15 \mathrm{mg} / \mathrm{L}$ for pirimicarb and $5 \mathrm{mg} / \mathrm{L}$ for diazepam containing $2 \mu \mathrm{L} / \mathrm{L}$ Tween 80) without food under standardized conditions for $48 \mathrm{~h}$. The concentrations were the same as those used for the pulsed exposure method in the multi-generational study. These experiments were performed in triplicate.

Total RNA was extracted from the 70 chironomids using a NucleoSpin ${ }^{\circledR}$ XS RNA kit (Takara BIO Inc., Shiga, Japan) according to the manufacturer's instructions. RNA samples were reverse-transcribed into complementary DNA using a PrimeScript ${ }^{\mathrm{Tm}}$ RT reagent kit with gDNA Eraser (Takara BIO Inc.) following the manufacturer's instructions. A TB Green ${ }^{\circledR}$ Premix EX Taq ${ }^{\text {TM }} /$ kit (Takara BIO Inc.) was used to detect the amplified products. The CAT, CYP450 and Hb genes were amplified using quantitative polymerase chain reaction (Real Time PCR System Quant Studio TM 12k Flex, Applied Biosystems, Thermo Fisher Scientific Inc. MA, USA) with the following primers. For CAT (mRNA; GenBank accession No. JL641904.1), the forward primer 5'-CGTGATCTTCGTGGTTTTGCTG-3' and reverse primer 5'- GGATTGGATCGCGGATGAAG -3' were used (Nair et al., 2011). For CYP450 (mRNA; GenBank accession No. FJ541450.1), the forward primer 5'-GACATTGATGAGAATGATGTTGGT-3' and reverse primer 5'-TAAGTGGAACTGGTGGGTACA-3' were used, whereas for the $\mathrm{Hb}$ gene (Hb IIB gene, GenBank accession No. AJ003807.1), the forward primer 5'-ATTCGCTGGAAAGGATGTTG-3' and reverse primer 5'-TATGAGACGAGTGAGGCACG-3' were used (Ha and Choi, 2008; Lencioni et al., 2016; Park et al., 2009). Actin (mRNA; GenBank accession No. AB070370.1) was used as the reference gene, with the forward primer 5'-GATGAAGATCCTCACCGAAC-3' and the reverse primer 5'-CCTTACGGATATCAACGTCG-3' (Lencioni et al., 2016). Amplification efficiencies of CAT, CYP450, $\mathrm{Hb}$, and actin in chironomids were $100 \%, 100 \%, 103 \%$, and $102 \%$, respectively. The expression data from the triplicate experiments were expressed relative to those of actin to normalize any difference in the reverse transcriptase efficiency and they were analyzed using the standard curve method. In the control and treatment groups for the multi-generational study, the ratio of mRNA levels in the treatment (15 mg/L for pirimicarb and $5 \mathrm{mg} / \mathrm{L}$ for diazepam) against each control $(0 \mathrm{mg} / \mathrm{L})$ in each generation were used as an index.

To confirm whether the CAT, CYP450 and Hb mRNA levels were related to the sensitivity, we investigated the relationship between sensitivity and mRNA levels using the generalized linear model (GLM) approach. 
The data were analyzed using R version 3.6.1 (R Development Core Team, 2019). The EC 50 values and standard errors were estimated by fitting acute toxicity data to a two-parameter log-logistic model, where the lower limit was fixed at 0 and the upper limit was fixed at 1 (Eqn. 2):

$$
f(x)=\frac{1}{\left(1+\exp (b(\log (x)-\log (e)))^{2}\right.}
$$

where, $f(x)$ is the probability of immobilization, $x$ is the nominal concentration of pirimicarb, $e$ is the inflection point of the fitted line (which is equivalent to the concentration required to cause a $50 \%$ response $\left.\left(\mathrm{EC}_{50}\right)\right)$, and $b$ is the relative slope around $e$. The triplicate testing of each test group was considered a random effect in the medrc package (Gerhard and Ritz, 2017). Significant differences between the $\mathrm{EC}_{50}$ values for the control and treatment groups from $\mathrm{F} 0$ to $\mathrm{F} 4$ were determined using the EDcomp function in the drc package (Ishimota et al., 2020b; Ritz et al., 2006). In this function, the ratios of the $\mathrm{EC}_{50}$ values were compared to 1 . Then, the significance level in each pair was adjusted using Holm's method (Holm, 1979).

For the CAT, CYP450 and $\mathrm{Hb}$ mRNA levels in the chironomids exposed to the four concentrations of each chemical, the variance of the groups was confirmed to be heterogeneous between the control and treatment groups (Levene's test) following Dunnett's test using the multcomp package (Hothorn et al., 2008). Significant differences between the $\mathrm{EC}_{50}$ values for the control and treatment groups from $\mathrm{F} 0$ to F4 were determined using the EDcomp function in the drc package (Ishimota et al., 2020b; Ritz et al., 2006). In this function, the ratios of the $\mathrm{EC}_{50}$ values were compared to 1 . Then, the significance level in each pair was adjusted using Holm's method (Holm, 1979). CAT, CYP450 and Hb mRNA levels in the samples from the multi-generational study were compared with a pairwise t-test using the $\mathrm{R}$ software program. For the multi-generational study, GLM analysis was used to estimate the effects of CAT, CYP450 and $\mathrm{Hb}$ mRNA levels and generational alternation (FO-F4) on the $\mathrm{EC}_{50}$ values. The $\mathrm{EC}_{50}$ values were assumed to be gamma (log-link) distributed. The selection of the best performance model (model with the lowest Akaike information criterion [AIC]) was based on AIC (Akaike, 1974). Full models included all variables (CAT, CYP450, and Hb mRNA levels, generational alteration (GA), the interaction between the GA

and each mRNA level. We tested the significance of the variables using the $\chi^{2}$ test $(P<0.05)$ based on the Wald statistic (Hosmer and Lemeshow, 2000; Marques et al., 2008).

\section{Results}

\section{Water quality and concentrations of chemicals}

For the pirimicarb treatment experiments, the temperature, $\mathrm{pH}$, and dissolved oxygen concentrations in the water ranged from 22.9 to $23.2^{\circ} \mathrm{C}, 8.15$ to 8.38 , and 7.92 to $9.03 \mathrm{mg} / \mathrm{L}$, respectively. For the diazepam treatment experiments, the temperature, $\mathrm{pH}$, and dissolved oxygen concentrations in the water ranged from 22.0 to $23.4^{\circ} \mathrm{C}, 8.17$ to 8.49 , and 8.19 to $9.08 \mathrm{mg} / \mathrm{L}$, respectively. During the tests, these parameters 
did not vary with treatment and remained within the criteria specified in the OECD test guideline No. 235 (OECD, 2011).

The mean recovery rate and RSDs for diazepam obtained from the three spiked water samples at 0.5 $\mu \mathrm{g} / \mathrm{L}$ were $101 \%$ and $2 \%$, respectively, and at $20 \mathrm{mg} / \mathrm{L}$ were $95 \%$ and $5 \%$, respectively. The mean ratio of the measured concentration to the nominal concentration of diazepam in the water samples after $48 \mathrm{~h}$ in the test condition was $105 \%$. The ratio of the measured to the nominal concentrations of pirimicarb and diazepam in the water samples at the start of exposure in the multi-generational experiment ranged from $82 \%$ to $94 \%$ and $82 \%$ to $114 \%$, respectively.

\section{Multi-generational experiment}

The best model approach showed that the $\mathrm{EC}_{50}$ values in the pirimicarb control group decreased with generational changes because the $p$-value obtained from the Wald statistics was $<0.05$ (Table 1). The $\mathrm{EC}_{50}$ value in the $\mathrm{F} 4$ control group differed significantly compared to the other generations (Fig. 2a). By contrast, $\mathrm{EC}_{50}$ values did not differ in the diazepam control groups (Fig. 2b).

In the F3 and F4 generations of the pirimicarb treatment group, the 48-h $\mathrm{EC}_{50}$ values $(38-43 \mu \mathrm{g} / \mathrm{L})$ were significantly higher than those of the control and other treatment groups $(18-30 \mu \mathrm{g} / \mathrm{L})$. These findings show that the chironomids became tolerant to pirimicarb during the multi-generational study. However, the model approach did not show a significant effect of generational alteration on the $\mathrm{EC}_{50}$ values for the pirimicarb treatment group (Fig. 2a and Table 1). In the diazepam treatment group, there was no significant difference in sensitivity to the chemicals throughout all generations (Fig. 2b); however, the best model approach showed that the increase in generational alteration was likely to be associated with an increase in $\mathrm{EC}_{50}$ value in the treatment group.

\section{CAT, CYP450, and Hemoglobin mRNA levels}

The CAT mRNA levels in the pirimicarb treatment group decreased significantly depending on the concentration, whereas the levels in the diazepam exposure group increased significantly depending on the concentration (Fig. 3a, b). The 48-h pirimicarb and diazepam exposure tests showed that the CYP450 mRNA levels in the different treatment groups decreased depending on the chemical concentration, despite there being no significant difference compared to the controls (Fig. 3c, d). This lack of significant difference in CYP450 might be owing to large variable errors in the samples. The Hb mRNA levels in the pirimicarb treatment group decreased significantly depending on the concentration, whereas the levels in the diazepam exposure group increased significantly depending on the concentration (Fig. 3e, f).

In the multi-generational experiment, a significant difference in the CAT mRNA levels was observed only in the F3 generation of the control group samples for pirimicarb (Fig. 4a). The best model approach showed that the decrease in CAT mRNA levels was likely to affect the increase in $\mathrm{EC}_{50}$ values in the pirimicarb treatment groups (Table 1). The CAT mRNA levels did not differ between the diazepam control and treatment group samples (Fig. 4b); however, the best model approach showed that the increase in 
CAT mRNA levels was likely to affect the increase in $\mathrm{EC}_{50}$ values in the control and treatment groups for diazepam. Despite a significant decrease in the interaction between the two variables (generational alteration and CAT levels) in the diazepam control group, it barely affected the $\mathrm{EC}_{50}$ values due to the small slope value (-0.064).

In the pirimicarb test groups, the CYP450 level in F3 was the highest in all the groups (Fig. 4c). For diazepam, the CYP450 level in the F0 control group was the highest among all samples (Fig. 4d). The best model approach showed that the CYP450 mRNA levels were not likely to affect the $\mathrm{EC}_{50}$ values in all the test groups for pirimicarb and diazepam (Table 1). Therefore, the model approach could not detect the effects of CYP450 on the $\mathrm{EC}_{50}$ values for both chemicals.

Although the $\mathrm{Hb}$ mRNA levels did not differ among the pirimicarb control groups, the levels in the treatment group significantly increased depending on the generation (Fig. 4e, f). The best model approach showed that the decrease in $\mathrm{Hb}$ levels in the treatment group may affect the $\mathrm{EC}_{50}$ values of pirimicarb, which is consistent with the results in Fig.3 e (Table 1). Additionally, the increase in the interaction between the two variables (generational alteration and $\mathrm{Hb}$ mRNA levels) in the treatment group was associated with increased $\mathrm{EC}_{50}$ values in the pirimicarb treatment group.

\section{Discussion}

Our previous study showed that $C$. yoshimatsui larvae (<24-h-old) exposed to pirimicarb had low sensitivity to the chemical in a multi-generational study (Ishimota et al., 2020a). In the present study, we used older-aged larvae ( $>24$ - and $<48$-h-old) compared to the previous study to obtain adequate amounts of mRNA using larger-sized chironomids. In the pirimicarb treatment group, the chironomids had a lower sensitivity than that of the control group (Fig. 2a). The maximum $48-\mathrm{h} \mathrm{EC}_{50}$ values (38-43 $\mu \mathrm{g} / \mathrm{L}$ ) in the larvae in the pirimicarb treatment group were lower than those of the chironomids used in the previous study (Ishimota et al., 2020a), suggesting that earlier exposure to this chemical might induce individuals with lower sensitivity. A previous study has shown increased pesticide tolerance to carbamate (carbaryl) in Lithobates sylvaticus (wood frog) when they were exposed to the chemical during their early life stage but not during their late life stage (Jones et al., 2018). The authors suggested that larval amphibians might use phenotypic plasticity in response to sublethal pesticide concentrations during early life stages but rely on naive tolerance during later life stages. Although our experimental design was limited for clarifying the different tolerances between the two ages, the metabolic pathway in the earlier staged larvae ( $<24$-h-old) might not be mature and might have more genes that could express for the response to the chemical compared to the later staged larvae ( $<48$-h-old).

CYP450 levels in the chironomids exposed to pirimicarb or diazepam decreased in a non-significant concentration-dependent manner (Fig. 3c, d). The decrease in the pirimicarb treatment group did not coincide with previous studies, where CYP genes were upregulated in chironomids exposed to an acetylcholine inhibitor (chlorpyrifos) (Tang et al., 2018). Martínez-Paz et al. (2012) reported that the CYP four family from Chironomidae responded selectively to xenobiotics chemicals. Thus, the response 
(upregulated or downregulated) of the CYP mRNA levels might not be predicted simply from the chemical classification. Results from the GLM analysis showed that CYP450 was not associated with the sensitivity alteration to diazepam in the multi-generational study (Fig. 4d and Table 1). In addition, the CYP450 hardly affected the sensitivity to pirimicarb (Fig. 4c and Table 1). Previous studies have shown that the upregulated CYP gene was associated with resistance in several insects (Kaplanoglu et al., 2017; Smith et al., 2018; Zhang et al., 2016); however, the CYP gene did not fully explain the low sensitivity in insects (Dulbecco et al., 2018). There are approximately 100 CYP450 in insects (Feyereisen, 1999); however, only a component of CYP450 was determined in the present study. The large errors between samples, as seen in the F3 or F4 generations in the pirimicarb treatment, may be one of the reasons why we could not determine the relationship between $\mathrm{EC}_{50}$ and CYP450 levels. Nevertheless, to determine whether CYP450 mRNA is related to larval sensitivity to these chemicals, further studies regarding the mRNA levels of other CYP450s are required.

When the chironomids were exposed to different concentrations of each chemical, the CAT or Hb mRNA levels responded differently to the target chemicals, e.g., the CAT or Hb mRNA levels in the pirimicarb exposure group decreased significantly depending on the concentration, whereas the levels in the diazepam exposure group increased significantly (Fig. 3a, b, e, f). These findings coincided with a previous study where $\mathrm{Hb}$ gene expression in Chironomidae showed chemical-specific responses (Lee et al., 2006). Decreased $\mathrm{Hb}$ gene expression was associated with increased oxygen consumption in $C$. tentans (Anderson et al., 2008), and decreased CAT mRNA levels might be due to the protective mechanism of the cells, which could protect the cells from oxidative stress caused by chemicals (Nair et al., 2011). Thus, pirimicarb might induce oxidative stress in the larvae. However, we could not explain the chemical tolerance to pirimicarb in the multi-generational experiments by altering the CAT mRNA levels (Fig. 4a and Table 1), suggesting that other oxidative enzymes, such as glutathione S-transferase, might be directly related to the modification of the oxidative stress of the chemical.

Several studies have shown that increased $\mathrm{Hb}$ levels contributed to increasing the lifespan and genotype frequency of aquatic organisms and improving immunity to toxic bacteria (Cambronero et al., 2018; Kawai et al., 2004; Yamamoto et al., 2003). The chemical-tolerant populations require more energy and resource allocation, which results in a fitness cost, e.g., decreased fecundity and increased larval development time (Kliot and Ghanim, 2012; Xie and Klerks, 2004; Postma et al., 1995). Because Hb is an important protein for the survival of chironomids under stressful conditions (Barbara, 1947; Kawai et al., 2004), we expected that the $\mathrm{Hb}$ mRNA levels in the low sensitivity chironomids associated with the test chemicals would decrease with the generational alteration as a fitness cost. However, the model approach showed that the chironomids in the pirimicarb treatment group trans-generationally became tolerant to the chemical by increasing their $\mathrm{Hb}$ mRNA levels (Fig. 4e and Table 1), which does not support our hypothesis. Nevertheless, our findings suggest that chironomids adapted to the oxidative chemical stress by increasing their $\mathrm{Hb}$ gene transcription. Organophosphate- and pyrethroid-resistant insects have several features such as higher body mass and more vacuoles, proteins, and carbohydrates compared to susceptible insects for higher stored energy (Kliot and Ghanim, 2012). The chironomids that had low 
sensitivity to pirimicarb had a larger body size when they became adults compared to the controls (Ishimota et al., 2020a). Considering these morphological modifications in the chemical-tolerant individuals, pirimicarb-tolerant chironomids might modify the protein components in their bodies and increased $\mathrm{Hb}$ transcription might be one of the strategies for adapting to oxidative chemical stress.

Although there has not been a study on the effects of diazepam on insect respiration, diazepam exposure has been shown to induce respiratory depression in humans (Forster et al., 1980). Thus, our findings suggest that chironomids exposed to diazepam modified their respiratory system by increasing CAT or $\mathrm{Hb}$ transcription (Fig. 3b, f). Despite the different responses between the two chemicals, CAT and $\mathrm{Hb}$ mRNA levels could be useful biomarkers. For the diazepam treatment groups in the multi-generational experiments, the $\mathrm{EC}_{50}$ was increased slightly depending on the generations, and the model approach showed that sensitivity decreased as the generations proceeded (Fig. 2b and Table 1). However, we could not find any mRNA levels that affected the sensitivity alteration. To ascertain possible sensitivity changes to diazepam, further studies examining the diazepam target site mRNA sequence, that is, the $G_{A B A}$ receptor in $C$. yoshimatsui (currently unknown), will be required because the mutation in the GABA receptor subunit is related to chemical (phenylpyrazole insecticide) resistance in other insects (Laodelphax striatellus, plant hopper) (Nakano, 2015). There is limited information regarding the interaction of pharmaceutical chemicals and aquatic organisms, and few studies have been undertaken that focus on chronic exposure to these chemicals (de Oliveira et al., 2018; Wu et al., 2020). Thus, further studies are required regarding the long-term effects of pharmaceutical chemicals to ascertain the potential risks or recovery of aquatic organisms from these chemicals.

In the present study, the GLM model approach might have overestimated the effects of each mRNA level on chemical sensitivity. For example, the significant effects of the interaction between the two variables (generational alteration and CAT mRNA levels) on the sensitivity in the diazepam control group. However, these interactions might not affect the sensitivity because 1) the slope value of the variable (interaction) in the pirimicarb treatment group was very small (-0.064) (Table 1) and 2) there was no significant difference in the sensitivity throughout the generations in the diazepam treatment group (Fig. 2b). The GLM model approach provides as high or higher statistical power than other common statistical methods, for example, the t-test (Tamai et al., 2018); therefore, the model might have overestimated the mRNA levels in the samples. The raw data must also be used when we evaluate the effects of variables on sensitivity using the GLM model.

In our previous study, we showed that the AChE activity might be associated with tolerance to pirimicarb in C. yoshimatsui (Ishimota et al., 2020a). The findings from the present study suggest that the chironomids recovered from the oxidative stress of pirimicarb by increasing their $\mathrm{Hb}$ mRNA levels, whereas CAT and CYP450 were not related to low sensitivity. The increasing Hb mRNA levels might not be directly associated with low sensitivity, but rather chironomids might adapt to the different chemicals by increasing their $\mathrm{Hb}$ gene transcription.

\section{Conclusion}


When chironomids were exposed to different concentrations of pirimicarb and diazepam, their CYP450 levels decreased in a non-significant concentration-dependent manner. In contrast, their CAT or Hb mRNA levels responded differently to the target chemicals; the CAT or $\mathrm{Hb}$ mRNA levels in the pirimicarb treatment groups decreased significantly depending on the concentrations, whereas the levels increased significantly in the diazepam treatment groups.

In the pirimicarb treatment group in the F3 and F4 generations, the chironomids had lower sensitivity than that of the control group, whereas the diazepam treatment group showed slightly lower sensitivity. The different sensitivity alterations between the two chemicals might be caused by different chemical classifications. Results from the GLM analysis showed that CAT and CYP450 were not associated with low sensitivity to pirimicarb in the multi-generational study; however, increasing $\mathrm{Hb}$ mRNA levels were associated with low sensitivity. Therefore, these levels might reduce the chemical stress by modifying the $\mathrm{Hb}$ gene transcription to adapt to oxidative chemical stress. In contrast, we could not find any mRNA levels related to the sensitivity changes in the diazepam treatment group. Further studies examining the diazepam target site mRNA sequence, that is, the $\mathrm{GABA}_{A}$ receptor, are needed.

\section{Declarations}

\section{Acknowledgments}

We thank our technical staff, Aya Kitahara, and Dr. Makio Takeda for their supports with this study. We also thank Dr. Kazutoshi Ohyama and Dr. Hiroaki Aoyama for allowing us to conduct this study and providing helpful comments. We thank Editage (https://www.editage.com/) for editing and reviewing this manuscript for English language.

Funding Not applicable.

Conflicts of interest/Competing interests The authors declare that they have no conflict of interest.

Ethics approvalThis research was conducted under the ethical standards of animal care in our institution.

Consent to participate Not applicable.

Consent for publication Not applicable.

Availability of data and material Not applicable.

Code availability Code for data analysis is provided as part of the package in the R software. The software is available at https://cran.r-project.org/mirrors.html.

Authors' contributions All authors contributed to the study conception and design. Data collection, material preparation, and data analysis were performed by Makoto Ishimota. The first draft of the 
manuscript was written by Makoto Ishimota and Naruto Tomiyama commented on revised versions of the manuscript. All authors read and approved the final manuscript.

\section{References}

1. Akaike H (1974) A new look at the statistical model identification. IEEE Trans. Autom. Control 19: 716-723.

2. Alfonso-Prieto M, Biarnes $X$, Vidossich P, Rovira C (2009) The Molecular Mechanism of the Catalase Reaction. J Am Chem Soc 131: 11751-11761.

3. Anderson TD, Jin-Clark Y, Begum K, Starkey SR, Zhu KY (2008) Gene expression profiling reveals decreased expression of two hemoglobin genes associated with increased consumption of oxygen in Chironomus tentans exposed to atrazine: A possible mechanism for adapting to oxygen deficiency. Aquat Toxicol 86: 148-156.

4. Ashauer R, Boxall ABA, Brown CD (2007) Modeling combined effects of pulsed exposure to carbaryl and chlorpyrifos on Gammarus Pulex. Environ Sci Technol 41: 5535-5541.

5. Barbara MW (1947) The function of haemoglobin in Tanytarsus (Chironomidae). J Exp Biol 24: 343351.

6. Böger B, do Amaral B, da Silveira Estevão PL, Wagner R, Peralta-Zamora PG, Gomes EC, (2018) Determination of carbamazepine and diazepam by SPE-HPLC-DAD in Belém River water, uritibaPR/Brazil. -Agua 13: 2.

7. Bonnafé E, Sroda S, Budzinski H, Valière A, Pedelluc J, Marty P, Geret F (2015) Responses of cytochrome P450, GST, and MXR in the mollusk Corbicula fluminea to the exposure to hospital wastewater effluents. Environ Sci Poll Res 22: 11033-11046.

8. Cambronero MC, Zeis B, Orsini L (2018) Haemoglobin-mediated response to hyper-thermal stress in the keystone species Daphnia magna. Evol Appl 11: 112-120.

9. Calamari D, Zuccato E, Castiglioni S, Bagnati R, Fanelli R (2003) A strategic survey of therapeutic drugs in the rivers Po and Lambro in northern Italy. Environ Sci Technol 37: 1241-1248.

10. Chen WY, Lin CJ, Ju YR, Tsai JW, Liao C-M (2012) Assessing the effects of pulsed waterborne copper toxicity on life-stage tilapia populations. Sci Total Environ 417-418: 129-137.

11. Choi J, Roche H (2004) Effect of potassium dichromate and fenitrothion on hemoglobins of Chironomus riparius Mg. (Diptera, Chironomidae) larvae: Potential biomarker of environmental monitoring. Environ Monit Assess 92: 229-239.

12. de Oliveira LLD, Nunes B, Antunes SC, Campitelli-Ramos R, Rocha $O$ (2018) Acute and chronic effects of three pharmaceutical drugs on the tropicalf cladoceran Ceriodaphnia silvestrii. Wat Air Soil-Poll 229: 116.

13. Dulbecco AB, Moriconi DE, Calderón-Fernández GM, Lynn S, McCarthy A, Roca-Acevedo G, Salamanca-Moreno JA, Juárez MP, Pedrini N (2018) Integument CYP genes of the largest genome- 
wide cytochrome P450 expansions in triatomines participate in detoxification in deltamethrinresistant Triatoma infestans. Sci Rep 8: 10177.

14. Feyereisen R (1999) Insect P450 enzymes. Annu Rev Entomol 44: 507-533.

15. Forster A, Gardaz JP, Suter PM, Gemperle M (1980) Respiratory depression by midazolam and diazepam. Anesthesiology 53: 494-

16. Gerhard D, Ritz C (2017) Marginalization in nonlinear mixed-effects models with an application to dose-response analysis. https://arxiv.org/abs/1707.02502 (accessed 6 May 2020).

17. Glykys J, Staley KJ (2015) Diazepam effect during early neonatal development correlates with neuronal $\mathrm{Cl}^{-}$. Ann Clin Transl Neurol 2: 1055-1070.

18. Ha M-H, Choi J (2008) Chemical-induced alteration of hemoglobin expression in the 4th instar larvae of Chironomus tentans (Diptera: Chironomidae). Environ Toxicol Pharmacol 25: 393-398.

19. Harris N, Baker J, Gray R (2009) Medicines management in mental health care. Wiley-Blackwell, Oxford.

20. Holm S (1979) A simple sequentially rejective multiple test procedure. Scand J Stat 6: 65-70.

21. Hosmer D, Lemeshow S (2000) Applied logistic regression. Wiley, New York.

22. Hothorn T, Bretz F, Westfall P, Heiberger RM, Schuetzenmeister A, Scheibe S (2008) Simultaneous inference in general parametric models. $R$ package version 1.4-8.

23. Ishimota M, Tajiki-Nishino R, Fukuyama T, Tomiyama N (2020a) Rapid adaptation of Chironomus yoshimatsui to acetylcholinesterase inhibitors (pyraclofos and pirimicarb) in a multi-generation study. J Environ Sci Health B 55: 429-437.

24. Ishimota M, Tajiki-Nishino N, Fukuyama T, Tomiyama N, Sakamoto M, Ohyama K (2020b) Long-term tolerance acquisition and changes in acetylcholinesterase activity in three cladoceran species after a 48-h pulsed exposure to pirimicarb. Wat Air Soi-Poll 231: 287.

25. Jones DK, Yates EK, Mattes BM, Hintz WD, Schuler MS, Relyea RA (2018) Timing and frequency of sublethal exposure modifies the induction and retention of increased insecticide tolerance in wood frogs (Lithobates sy/vaticus). Environ Toxicol Chem 37: 2188-2197.

26. Kaplanoglu E, Chapman P, Scott IM, Donly C (2017) Overexpression of a cytochrome P450 and a UDP-glycosyltransferase is associated with imidacloprid resistance in the Colorado potato beetle, Leptinotarsa decemlineata. Sci Rep 7: 1762. doi:10.1038/s41598-017-01961-4

27. Kawai K, Hashimoto M, Imabayashi H (2004) Environmental factors affecting the quality and quantity of hemoglobin in Chironomus larvae (Diptera: Chironomidae). Med Entomol Zool 55: 281287.

28. Kliot, A., Ghanim. M., 2012. Fitness costs associated with insecticide resistance. Pest Manag Sci 68: 1431-1437.

29. Lee SM, Lee SB, Park CH, Choi J (2006) Expression of heat shock protein and hemoglobin genes in Chironomus tentans (Diptera, Chironomidae) larvae exposed to various environmental pollutants: A potential biomarker of freshwater monitoring. Chemosphere 65: 1074-1081. 
30. Lencioni V, Grazioli V, Rossaro B, Bernabò P (2016) Transcriptional profiling induced by pesticides

31. employed in organic agriculture in a wild population of Chironomus riparius under laboratory conditions. Sci Total Environ 557-558: 183-191.

32. Manfrin A, Larsen S, Scalici M, Wuertz S, Monaghan, MT (2018) Stress response of Chironomus riparius to changes in water temperature and oxygen concentration in a lowland stream. Ecol Indic 95: $720-725$.

33. Martínez-Paz P, Morales M, Martínez-Guitarte JL, Morcillo G (2012) Characterization of a cytochrome P450 gene (CYP4G) and modulation under different exposures to xenobiotics (tributyltin, nonylphenol, bisphenol A) in Chironomus riparius aquatic larvae. Comp Biochem Physiol C 155: 333-343.

34. Marques SC, Azeiteiro UM, Leandro SM, Queiroga H, Primo AL, Martinho F, Viegas I, Pardal MA (2008) Predicting zooplankton response to environmental changes in a temperate estuarine ecosystem. Mar Biol 155: 531-541.

35. McLellan SL, Sauer EP, Corsi SR, Bootsma MJ, Boehm AB, Spencer SK, Borchardt MA (2018) Sewage loading and microbial risk in urban waters of the Great Lakes. Elementa-Sci Anthrop 6: 46.

36. Nair PMG, Park SY, Choi J (2011) Expression of catalase and glutathione S-transferase genes in Chironomus riparius on exposure to cadmium and nonylphenol. Comp Biochem Physiol C 154. 399408.

37. Nair PMG, Park SY, Choi J (2013) Characterization and expression of cytochrome p450 cDNA (CYP9AT2) in Chironomus riparius fourth instar. Environ Toxicol Pharmacol 33: 1133-1140

38. Nakano T (2015) Study on the structure and insecticide sensitivity of the RDL GABA receptor. J Pest Sci 40: 152-159.

39. Organization for Economic Co-operation and Development (OECD) (2011) OECD guidelines for testing of chemicals: No.235: Chironomus, Acute immobilisation test, OECD guidelines for the testing of chemicals, Section 2. doi:10.1787/9789264122383-en.

40. Park K, Bang HW, Park J, Kwak IS (2009) Ecotoxicological multilevel-evaluation of the effects of fenbendazole. Chemosphere 7: 359-367.

41. Pascoe D, Karntanut W, Müller CT (2003) Do pharmaceuticals affect freshwater invertebrates? A study with the cnidarian Hydra vulgaris. Chemosphere 51: 521-528.

42. Postma JF, van Kleunen A, Admiraal W (1995) Alterations in life-history traits of Chironomus riparius (Diptera) obtained from metal contaminated rivers. Arch Environ Contam Toxicol 29: 469-475.

43. R Development Core Team (2019) R: A language and environment for statistical computing. Version 3.6.1. R Foundation for Statistical Computing, Vienna, Austria.

44. Ritz C, Cedergreen N, Jensen JE, Streibig JC (2006) Relative potency in nonsimilar dose-response curves. Weed Science 54: 407-412.

45. Smith LB, Tyagi R, Kasai S, Scott JG (2018) CYP-mediated permethrin resistance in Aedes aegypti and evidence for trans-regulation. PLOS Negl Trop Dis 2018;12:e0006933 
46. Struger J, Grabuski J, Cagampan S, Sverko Ed, Marvin C (2016) Occurrence and distribution of carbamate pesticides and metalaxyl in southern Ontario surface waters 2007-2010. Bull Environ Contam Toxicol 96: 423-431. https://10.1007/s00128-015-1719-x

47. Tamai S, Iwasaki Y, Ishimota M, Kashiwada S (2018) Generalized linear models for statistical analysis of binary data: Time to get rid of using fraction [in Japanese]. Jpn J Environ Toxicol 20: 5158.

48. Tang G, Yao J, Li D, He Y, Zhu YC, Zhang X, Zhu KY (2017) Cytochrome P450 genes from the aquatic midge Chironomus tentans: Atrazine-induced up-regulation of CtCYP6EX3 enhanced the toxicity of chlorpyrifos. Chemosphere 186: 68-77.

49. Tang G, Yao J, Zhang X, Lu N, Zhu KY (2018) Comparison of gene expression profiles in the aquatic midge (Chironomus tentans) larvae exposed to two major agricultural pesticides Chemosphere 194: 745-754.

50. Ternes T, Bonerz M., Schmidt T (2001) Determination of neutral pharmaceuticals in wastewater and rivers by liquid chromatography-electrospray tandem mass spectrometry. J. Chromatography A 938 : 175-185.

51. Trac LN, Andersen O, Palmqvist A (2016) Deciphering mechanisms of malathion toxicity under pulse exposure of the freshwater cladoceran Daphnia magna. Environ Toxicol Chem 35: 394-404. https://doi.org/10.1002/etc.3189

52. Wang R-S, Nakajima T, Honma T (1999) Different change patterns of cytochrome P450 and glutathione chemically induced liver damage the isozymes $S$-transferases in rat. Ind Health 37 : 440-448.

53. Wu K, Hoy MA. (2016) The glutathione-S-transferase, cytochrome P450 and carboxyl/cholinesterase gene superfamilies in predatory mite Metaseiulus occidentalis. PLOS ONE 11: e0160009.

54. Wu M, Qiu X, Chen C, Chen K, Li M, Xu H, Wu X, Shimasaki Y, Oshima Y (2020) Short-term and persistent impacts of sublethal exposure to diazepam on behavioral traits and brain GABA levels in juvenile zebrafish (Danio rerio). Sci Total Environ 740:140392.

55. Xie L, Klerks P (2004) Fitness cost of resistance to cadmium in the least killifish (Heterandria formosa). Environ Toxicol Chem 23: 1499-1503.

56. Xiong W, Ga S, Mao J, Wei L, Xie J, Liu J, Bi J, Song X, Lia B (2019) CYP4BN6 and CYP6BQ11 mediate insecticide susceptibility and their expression is regulated by Latrophilin in Tribolium Pest Manag Sci 75: 2744-2755.

57. Yamamoto A, Nagura J, lida T (2003) Influence of hemoglobin concentration on tolerance to

58. bacterial gill disease in Rainbow Trout. Fish Pathology 38: 99-103.

59. Yu TH, Dafre AL, de Aragão Umbuzeiro G, Franciscon E (2015) CYP-dependent induction of glutathione S-transferase in Daphnia similis exposed to a disperse azo dye. Ecotoxicology 24: 232237.

60. Zhang B, Zhang L, Cui R, Zeng X, Gao X (2016) Cloning and expression of multiple cytochrome P450 genes: Induction by fipronil in workers of the red imported fire ant (Solenopsis invicta Buren). PLoS 
ONE 8: 10177.

\section{Tables}

Table 1 Generalized linear model (GLM) for 48-h $\mathrm{EC}_{50}$ values to estimate the effects of pirimicarb and diazepam on the variables (generational alternation, CAT, CYP450, and hemoglobin mRNA levels) 


\begin{tabular}{|c|c|c|c|c|c|c|}
\hline \multirow[t]{2}{*}{$\begin{array}{l}\text { Group } \\
\text { name }\end{array}$} & \multirow[t]{2}{*}{ Variable } & \multicolumn{3}{|c|}{$\begin{array}{l}\text { Parameter coefficients in best } \\
\text { model }\end{array}$} & \multicolumn{2}{|l|}{ AIC } \\
\hline & & Slope & $\operatorname{Pr}(>|t|)$ & & $\begin{array}{l}\text { Best } \\
\text { model }\end{array}$ & $\begin{array}{l}\text { Full } \\
\text { model }\end{array}$ \\
\hline Primicarb & Intercept & 3.441 & $<2.0 \times 10^{-16}$ & 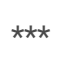 & 18.0 & 20.2 \\
\hline \multirow[t]{5}{*}{$\times$ Control } & $\begin{array}{l}\text { Generational alternation } \\
(\mathrm{GA})\end{array}$ & -0.1011 & $1.48 \times 10^{-7}$ & 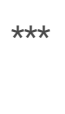 & & \\
\hline & CAT mRNA level (CAT) & -0.081 & 0.125 & & & \\
\hline & CYP450 mRNA level(CYP) & -0.004 & 0.151 & & & \\
\hline & $\begin{array}{l}\text { Hemoglobin mRNA level } \\
(\mathrm{Hb})\end{array}$ & -0.081 & 0.122 & & & \\
\hline & $\mathrm{GA} \times \mathrm{CAT}$ & 0.021 & 0.123 & & & \\
\hline Primicarb & Intercept & 3.354 & $<2.0 \times 10^{-16}$ & 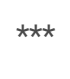 & 43.0 & 46.9 \\
\hline \multirow[t]{4}{*}{$\begin{array}{l}\times \\
\text { Treatment }\end{array}$} & $\begin{array}{l}\text { Generational alternation } \\
(\mathrm{GA})\end{array}$ & -0.016 & 0.186 & & & \\
\hline & CAT mRNA level (CAT) & -0.161 & $3.85 \times 10^{-6}$ & $* * *$ & & \\
\hline & $\begin{array}{l}\text { Hemoglobin mRNA level } \\
(\mathrm{Hb})\end{array}$ & -1.360 & $3.01 \times 10^{-5}$ & $* \star \star$ & & \\
\hline & $\mathrm{GA} \times \mathrm{Hb}$ & 0.317 & $1.02 \times 10^{-5}$ & 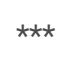 & & \\
\hline Diazepam & Intercept & 2.082 & $6.00 \times 10^{-8}$ & $* \star \star$ & 31.2 & 33.5 \\
\hline \multirow[t]{4}{*}{$\times$ Control } & $\begin{array}{l}\text { Generational alternation } \\
\text { (GA) }\end{array}$ & 0.005 & 0.061 & & & \\
\hline & CAT mRNA level (CAT) & 0.165 & 0.010 & * & & \\
\hline & $\begin{array}{l}\text { Hemoglobin mRNA level } \\
(\mathrm{Hb})\end{array}$ & 0.036 & 0.036 & * & & \\
\hline & $\mathrm{GA} \times \mathrm{CAT}$ & -0.064 & 0.004 & $\star \star$ & & \\
\hline Diazepam & Intercept & 1.976 & $5.1 \times 10^{-8}$ & $* \star \star$ & 37.4 & 39.4 \\
\hline \multirow[t]{4}{*}{$\begin{array}{l}\times \\
\text { Treatment }\end{array}$} & $\begin{array}{l}\text { Generational alternation } \\
\text { (GA) }\end{array}$ & 0.103 & 0.006 & $\star *$ & & \\
\hline & CAT mRNA level (CAT) & 0.248 & 0.014 & * & & \\
\hline & CYP450 mRNA level(CYP) & -0.015 & 0.086 & & & \\
\hline & $\begin{array}{l}\text { Hemoglobin mRNA level } \\
(\mathrm{Hb})\end{array}$ & -0.053 & 0.177 & & & \\
\hline
\end{tabular}


The symbol $(x)$ shows the interaction between the two variables

Asterisks represent the explanatory variables $\left({ }^{\star} p<0.05,{ }^{\star *} p<0.01,{ }^{\star \star \star} p<0.001\right.$ with Wald statistics)

\section{Figures}

\begin{tabular}{|c|c|c|c|c|}
\hline F0-control group & & Adults & \multirow{2}{*}{$\begin{array}{l}\text { Exposure } \\
\text { to chemical }\end{array}$} & \multirow{4}{*}{$\begin{array}{l}\cdot \mathrm{EC}_{50} \text { value } \\
\cdot \text { CAT,CYP450, and } \mathrm{Hb} \\
\text { mRNA levels }\end{array}$} \\
\hline - FC value & Exposure & \multirow[b]{2}{*}{ Larvae produced $(<48 \mathrm{~h}$ old $)$} & & \\
\hline CAT CYP450 and Hh & to cnemical & & & \\
\hline mRNA levels & & & & \\
\hline
\end{tabular}

No exposure to chemical for $48 \mathrm{~h}$

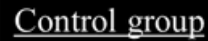

Culture without

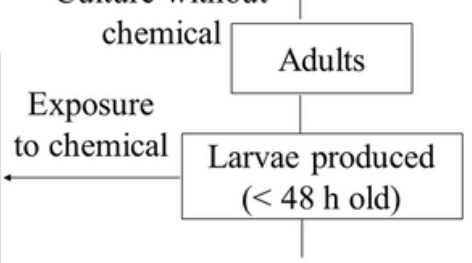

No exposure to chemical for $48 \mathrm{~h}$

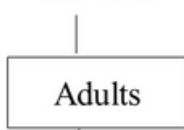

Exposure to chemical for $48 \mathrm{~h}$

Treatment group

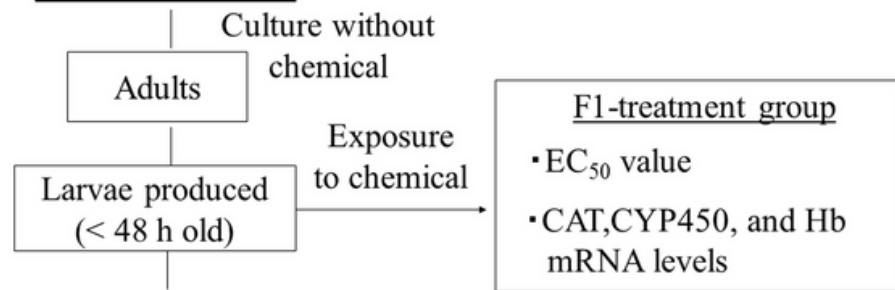

Exposure to chemical for $48 \mathrm{~h}$

Adults

Same procedure for F2-F4

\section{Figure 1}

Schematic view of the multi-generational experimental design in Chironomus yoshimatsui exposed to pirimicarb and diazepam in each generation. To set up the treatment groups, test larvae (<48-h-old) were exposed to solutions containing each insecticide $(0$ and $15 \mathrm{mg} / \mathrm{L}$ of pirimicarb and 0 and $5 \mathrm{mg} / \mathrm{L}$ of diazepam) containing $2 \mu \mathrm{L} / \mathrm{L}$ Tween 80 before each. For each generation, test larvae were exposed to six concentrations of each chemical $(0,1.3,2.5,5,10$, and $20 \mathrm{mg} / \mathrm{L}$ for diazepam; $0,5,10,20,40$, and 80 $\mathrm{mg} / \mathrm{L}$ for pirimicarb) to calculate the $48-\mathrm{h}$ EC50 values $(\mathrm{n}=3)$. CAT, CYP450, and Hb mRNA levels in the larvae (<48-h-old) from the control and treatment groups were determined after exposure to test solutions $(0$ and $15 \mathrm{mg} / \mathrm{L}$ of pirimicarb and 0 and $5 \mathrm{mg} / \mathrm{L}$ of diazepam containing $2 \mu \mathrm{L} / \mathrm{L}$ Tween 80$)$ for $48 \mathrm{~h}(\mathrm{n}=$ 


\section{a: Pirimicarb}

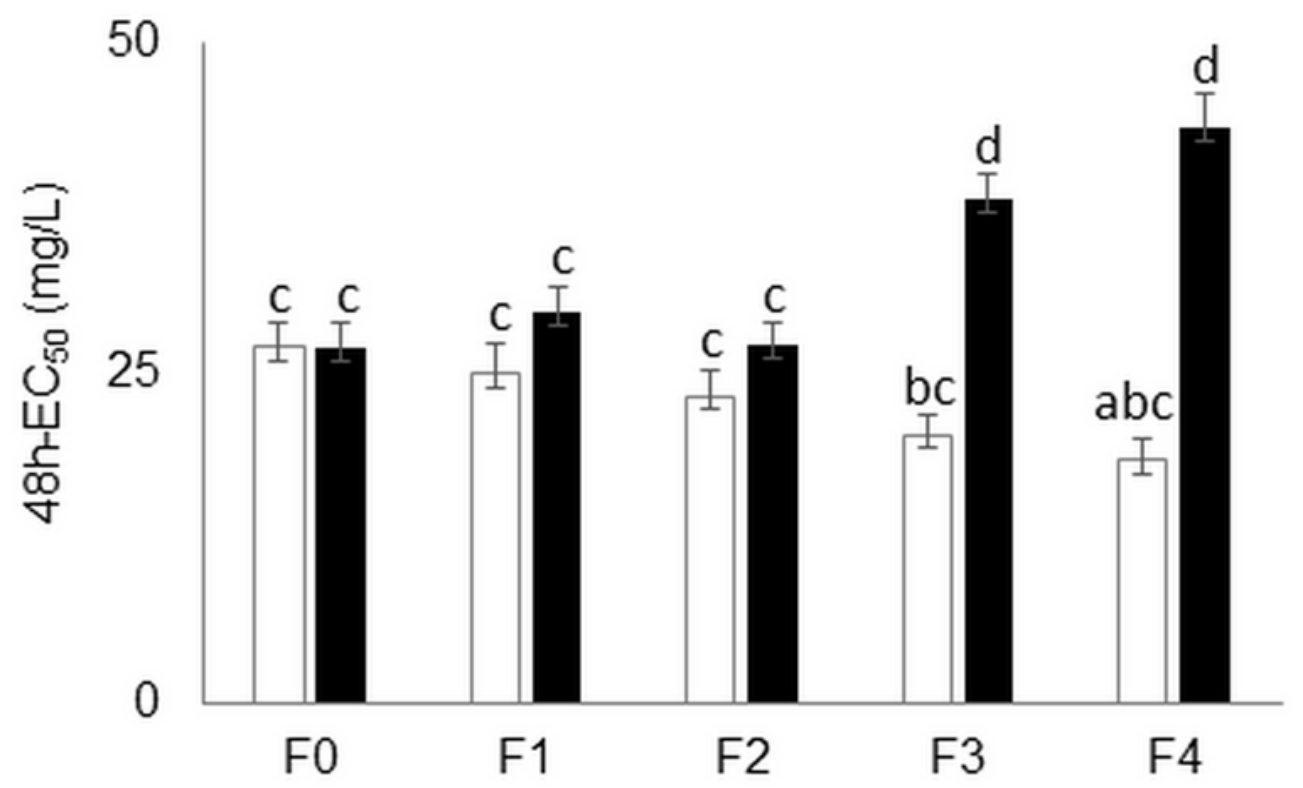

\section{b: Diazepam}

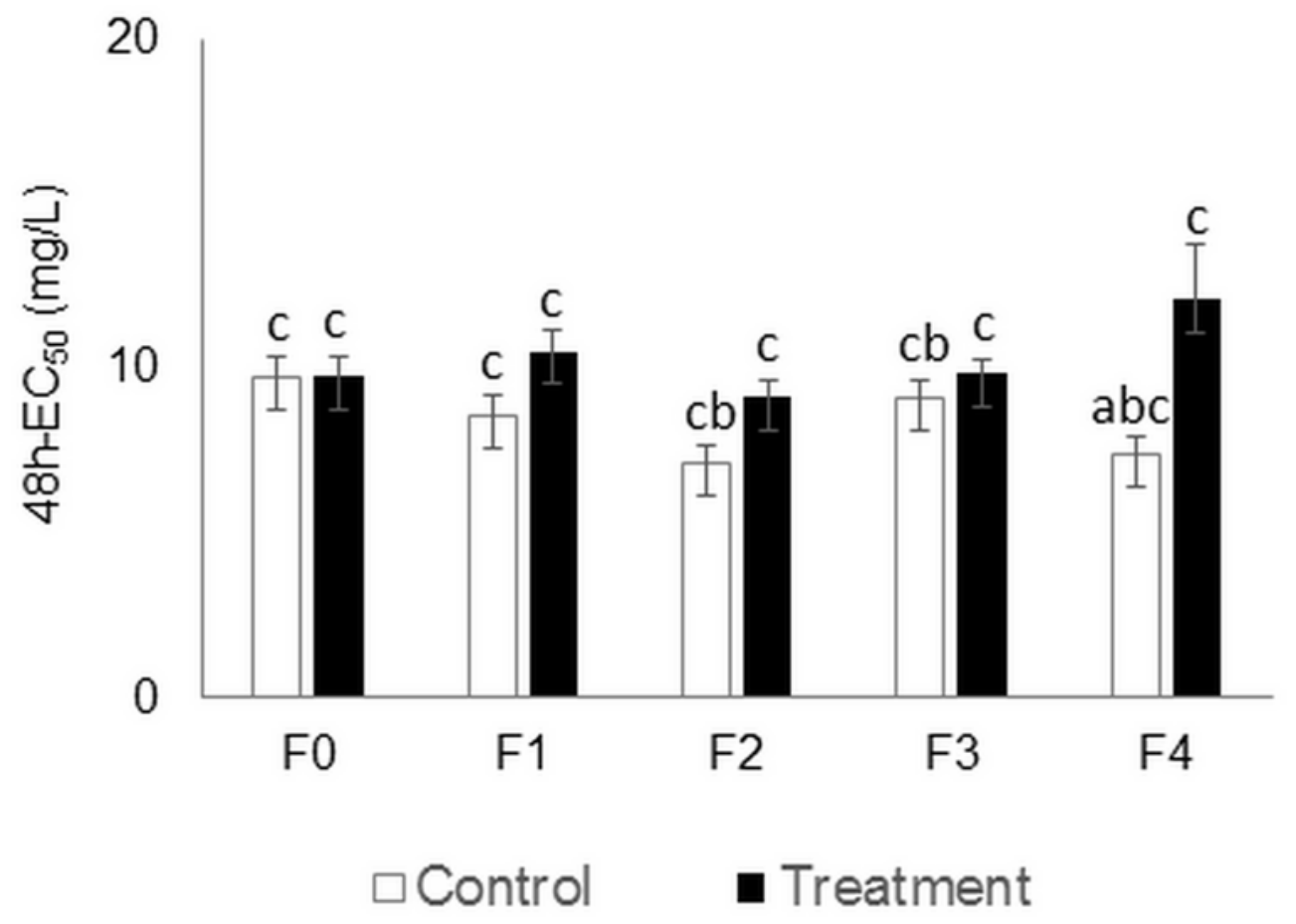

Figure 2

Changes in 48-h EC50 values for Chironomus yoshimatsui (< 48-h-old) exposed to (a) pirimicarb and (b) diazepam (open bars: control groups, closed bars: treatment groups) in the multi-generational study. The EC50 values were calculated from three independent experiments. Different letters in panels $a-b$ show significant differences. Error bars denote standard error of the estimated value 

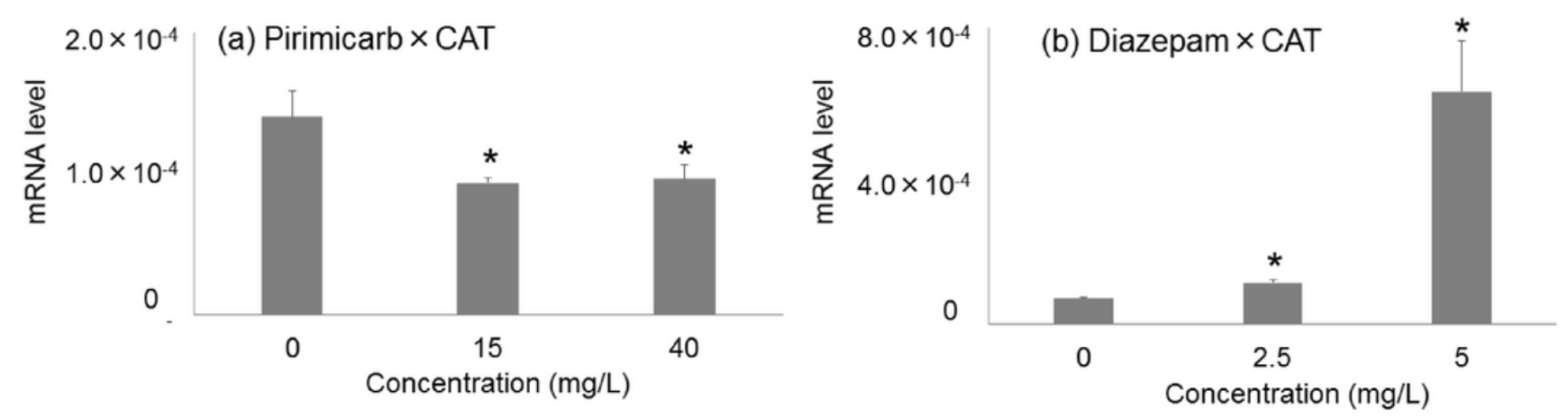

(c) Pirimicarb $\times$ CYP450
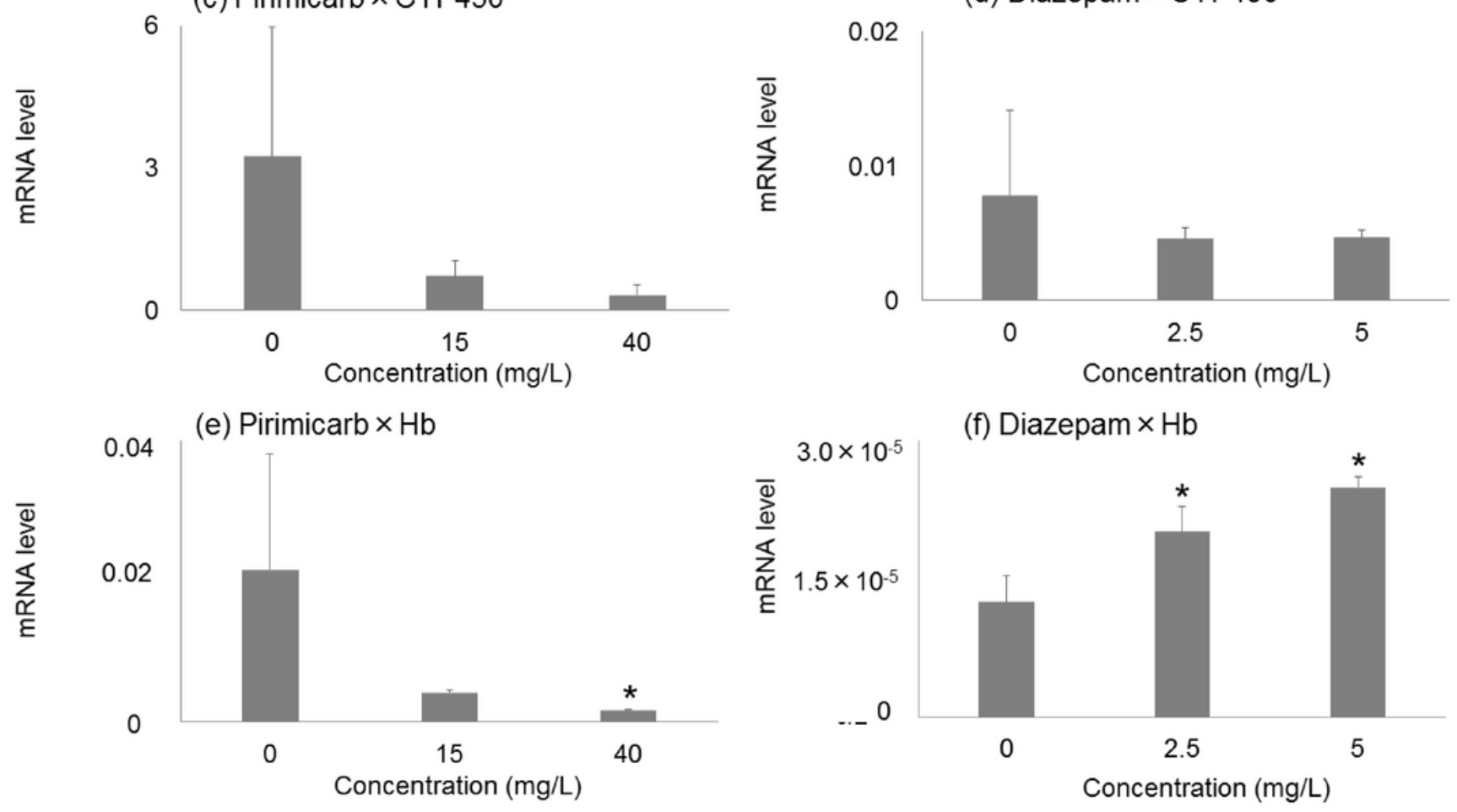

Figure 3

CAT (a, b), CYP450 (c, d), and Hb (e, f) mRNA levels in Chironomus yoshimatsui (< 48-h-old) exposed to pirimicarb (a, c: 0,15 , and $40 \mathrm{mg} / \mathrm{L}$ ) and diazepam (b, d: $0,2.5$, and $5 \mathrm{mg} / \mathrm{L}$ ) for $48 \mathrm{~h}$ (total individuals = 210: 70 individuals/sample $\times n=3$ ). Data represent the mean \pm standard deviation (mRNA gene expression levels, $n=3$ ). Asterisks show a significant difference compared to that of the control group ( $p$ $<0.05)$ 

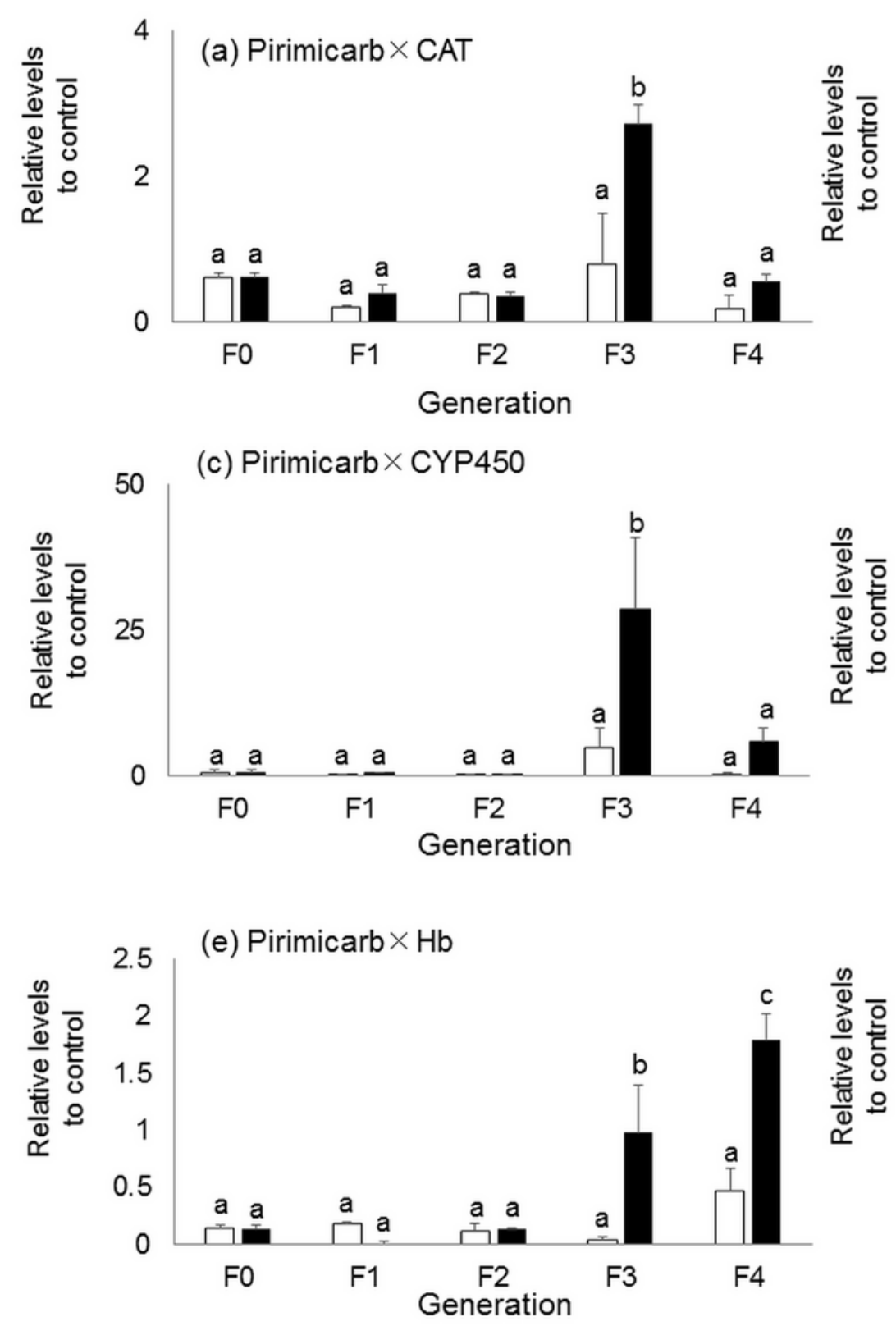

6
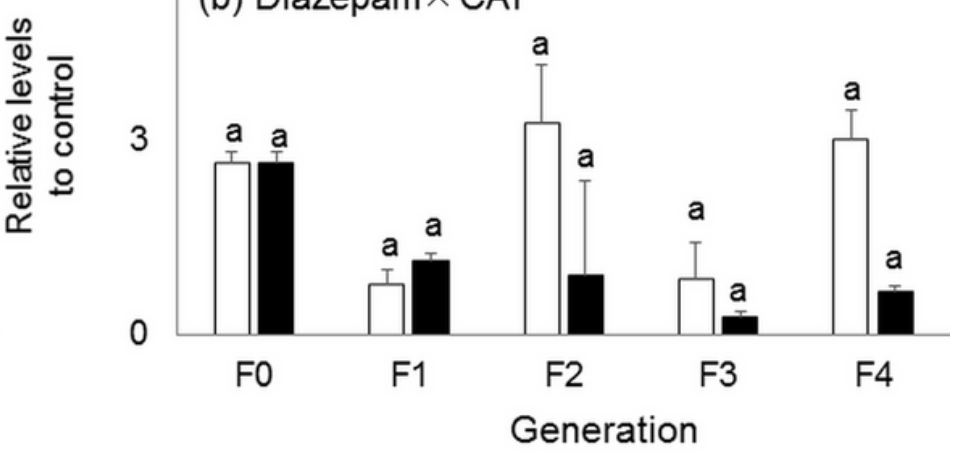

30

(d) Diazepam $\times$ CYP450

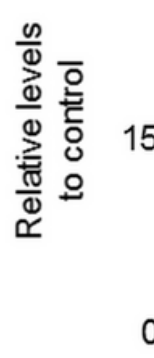

15

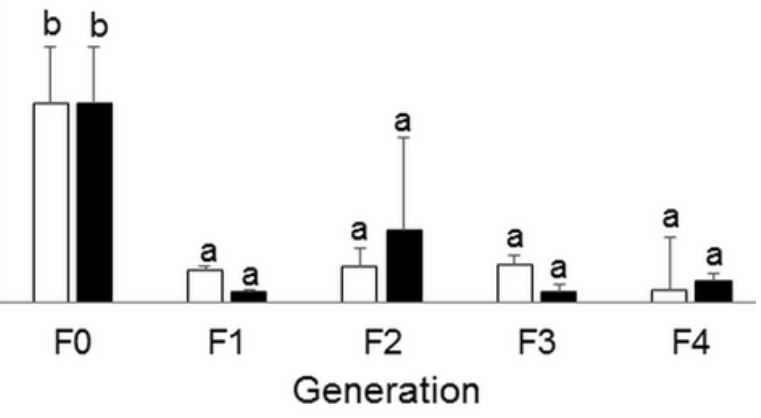

6 (f) Diazepam $\times \mathrm{Hb}$

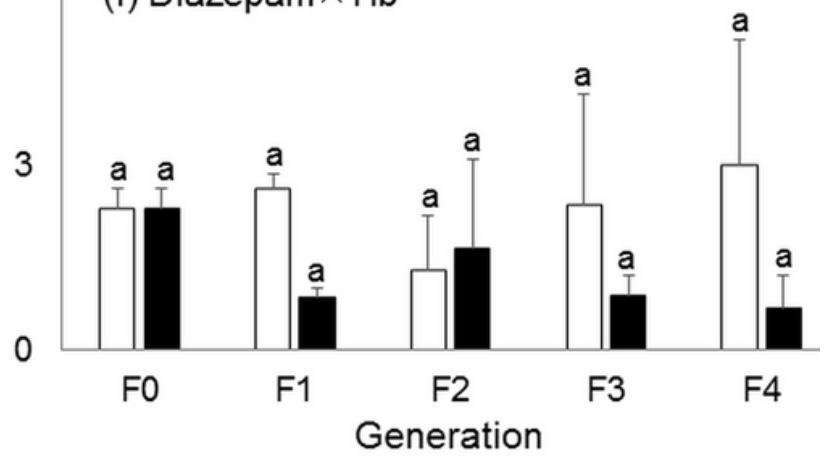

Figure 4

CAT (a, b), CYP450 (c, d), and $\mathrm{Hb}(\mathrm{e}, \mathrm{f})$ mRNA relative levels (to each control, $0 \mathrm{mg} / \mathrm{L}$ ) in Chironomus yoshimatsui (< 48-h-old) exposed to pirimicarb (a, c: $15 \mathrm{mg} / \mathrm{L}$ ) and diazepam (b, d: $5 \mathrm{mg} / \mathrm{L}$ ) for $48 \mathrm{~h}$ in the control group (without pulsed exposure of each chemical, open bars) and treatment group (with pulsed exposure of each chemical, closed bars) in the multi-generational study (total individuals $=210: 70$ individuals/sample $\times n=3$ ). Data represent the mean \pm standard deviation (relative levels to control, 0 $\mu g / L, n=3)$. Different letters in panels a-f show significant differences 